\title{
Amnesty Limits in International Criminal Law
}

\author{
Diakaridia Fomba ${ }^{1}$, Muhammad Misbahul Mujib ${ }^{1,2}$ \& Ahmed Hedieloum Kodio ${ }^{1}$ \\ ${ }^{1}$ Law School, Zhongnan University of Economics and Law, Wuhan, China \\ ${ }^{2}$ Lecturer at Sunan Kalijaga State Islamic University, Yogyakarta, Indonesia/Ph.D candidate, Zhongnan \\ University of Economics And Law, Wuhan, China \\ Correspondence: Diakaridia Fomba, Law School, Zhongnan University of Economics and Law, Wuhan, China. \\ E-mail: diakfob3@163.com
}

Received: April 20, 2020

Accepted: May 19, $2020 \quad$ Online Published: May 20, 2020

doi:10.5539/jpl.v13n2p69

URL: https://doi.org/10.5539/jpl.v13n2p69

\begin{abstract}
This article examine the problems raised by amnesty in the domestic and international legal order in the context of national reconciliation. It examines the scope and limits of the amnesty law, justifying it by the exceptions made for international crimes and violations as far as international humanitarian law is concerned. Indeed, this paper deals with the domestic and international legal aspects of non-amnesty crimes that are recognized under conventional and customary international law as imprescriptible, through the experience of specialized international courts on the subject such as those of Rwanda, Sierra Leone, and the ICC.
\end{abstract}

Keywords: amnesty, crimes against humanity, war crimes, genocide, ethnic cleansing

\section{Introduction}

In states, civil or internal armed conflict, the authorities in charge most often use legal actions to complement the efforts of achieving political reconciliation among citizens. Amnesty is internationally recognized as a signal of peace that is shown at the end of most conflict in the world. The term "amnesty" is a Greek word from

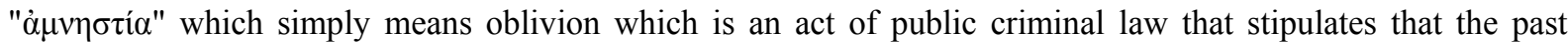
misconducts of an individual or groups should be forgotten or forgiven and it also prevents anyone from meting out penalty or punishment to such individuals or group of persons.

Since ancient times, amnesty clauses have existed in all peace treaties that are concluded to deal with war situations. One of Trasybule's first amnesty laws can be traced as far back to 405 (B-C) during the Peloponnesian War (Koudou, 2004). Today, it is increasingly used in pacification laws that end a civil war in the contemporary world. The purpose of the Act is to seek a peaceful way of resolving a just ended conflict to avoid a situation where individuals will be seeking new claims and complaints that has the possibility of re-igniting hostilities between the war parties.

In Legal terms, amnesty is a legal concept which is synonymous to legal forgiveness. "Without alleviating the material facts and their civil consequences, the law of amnesty, extinguishes public action and cancels the sentence pronounced" (Guillien, 2003). This definition shows that it is an act of the internal legislator that retroactively cancels the punishable nature of the acts to which it applies. As a result, sanctions and acts of amnesty no longer appear on the criminal record of such individual or group of persons. Under national law, amnesty could be equated to the previously sovereign presidential right of pardon as set up in many countries like France according to its decree on 14 September 1791 (décret, 1791). The reality is that the privilege of granting forgiveness is the sole right of the President of the Republic as stated in the constitution, while granting amnesty in most cases is that of the National Assembly (Wahnich, 2007). The latter allowed the establishment of the Republic and with democracy as the system of government as demanded by the French constitution in the former colonies of France. After the revolution of 1789 (Stéphane Gacon, 2009) (Caron, 2012), it continues to facilitate the process of peacebuilding in conflict-ridden African states such as Rwanda, Sierra Leone and currently in Mali. .

In practice, however, most amnesty laws are now negotiated in advance when concluding peace agreements. These measures relate to certain category of offenses punishable under national law. Other categories of crimes are also recognized by the United Nations and customary international law as imprescriptible and are eliminated from the setting of amnesty prerogative, although there are guarantee of post-war reconciliation. This therefore, 
raises some questions such as what legal scope is covered by amnesty. Where are its limits? And are these limits justifiable under international law?

These questions are in two fold. On a theoretical level, they shed light on the legal field reserved for amnesty law and what is prohibited. On a practical level, they decipher the practices that justify the limitation of amnesty in international law. This article examines the scope, limits, and justifications of them.

\section{Scope of Application}

In situations of internal conflict, the scope of the amnesty law includes acts classified as crimes or breaches that are foreseen and punished by the penal code of the State in question. In the general sense, as far as the Law on Amnesty is concerned, a misdemeanor or breaches is synonymous to an offence. Strictly speaking, it is a crime whose offender is punished with corrective sanctions. Therefore in the Malian criminal code of 2001, the sanctions that can be applied to the individual or group of persons in such a situation are imprisonment of a maximum of six months to ten years, fines, deprivation or limitation of rights, and other additional sanctions. As for legal entities, only fines and penalties that limit rights are applied. Criminal law considers it as an ordinary or even political crime, punishable by life imprisonment or fixed-term imprisonment for individuals found in such situations. The penalties given to legal persons who commit such crimes also apply to crimes that they commit in other circles according to the stipulated laws of the country concerned.

It includes other criminal laws and international conventions and texts ratified by the country in the area of safeguarding and the promotion of human rights, which arise in the context of events related to crisis that arose in a specific period. These crimes must have seriously undermined national unity and social cohesion, as in the case of Mali since 2012 ( $\left.\mathrm{N}^{\circ} 2019-042 / \mathrm{AN}-\mathrm{RM}, 2019\right)$, Sierra Leone and Rwanda. Some political measure is intended to exempt certain action, such as the perpetrators as well as their accomplices who committed any crime against humanity which include but not limited to assassination and destruction of property.

These exemptions from prosecution refer to people who are not convicted in absentia, people wanted internally, and people outside the country who are members of groups that have signed a peace agreement, as well as members of one of the armed groups that are not signatories, but have joined the peace agreement. Therefore, amnesty creates the benefit of national forgiveness for all those who have committed or have been accomplice in the convicted acts. However, these national measures must strictly comply with universal standards applicable to the subject of international law in relation to the law on amnesty.

\section{Limitations}

These limits refer to the norms of international law or "jus cogens" that now appear in the document of the 2005 World Summit. This document formalizes the obligation to protect the population from the crimes that are considered to be serious, namely war crimes, genocide, crimes against humanity, and ethnic cleansing. It recognizes that fundamental human rights principles prohibit such violations. Compliance with these standards is, therefore, an erga omnes obligation of States and the international community.

\subsection{Crime against Humanity}

It should be noted that there is no uniform definition of "crime against humanity". The lists of crimes that appear in international texts are different. Article 6 (c) of the Nuremberg Tribunal defines it as massacre, extinction, slavery, expulsion and any other cruel act perpetrated against a noncombatant populace, before or throughout the war, or persecution, which constitutes a breach of the national laws of the country in which the crime happened, as a result or in relation to any wrongdoing within the dominion of the Court.

Subsequently, this definition has been expanded over the years. In 1973, the Global Convention on "Repression and Punishment of the Crime of Apartheid" explains and describes apartheid as a crime against humanity (Convention international sur l'élimination et la répression du crime d'apartheid par l'Assemblée général des Nations Unis, 1973). In 1992, a resolution classified the kidnapping of people followed by their disappearance as a crime in the framework of crimes committed against humanity (Resolution 47/133, 1992). The ICTY maintains the same list of crimes, but specifies that such acts needs to be committed in the framework of an extensive and orderly attack that is perpetrated against any noncombatant populace, regardless of their citizenship, partisan, cultural, ethnic or religious association ( ICTY Statute , 1993). Here ICTY adds to the Nuremberg definition by including deportation, imprisonment, torture and rape.

The ICC Statute defines eleven acts that could be categorized as crimes against humanity if they are occurred in the framework of a prevalent or organized attack directed against a noncombatant populace, with the intention of attacking: assassination; extinction ; slavery; expulsion or forced transfer of the population; detention or other serious denial of physical freedom that breach the fundamental provisions of international law; agony; rape, 
sexual slavery, compulsory prostitution, forced gestation, obligatory cleansing or other categories of sexual abuse; maltreatment of any recognizable people or community for partisan, ethnic, racial, cultural, religious, national, gender or other reasons that are globally known as not permitted by international Instruments, in relation to any act mentioned in this section or any wrongdoing within the influence of the court that cause desertion of people, crime of apartheid and other cruel activities (ICC Statute, 1998). The ICC statute is expanding the list of acts from time to time to cover other inhuman acts intentionally perpetrated against individuals.

According to the ICTY, these attacks carried out are equated to an armed conflict because crimes against humanity, by definition, would be arisen in the context of an armed clash. Therefore, the violence should be targeted against any noncombatant populace (ICTY, Appeal Chamber, judgment condamning Dusko Tadic, $\mathrm{n}^{\circ}$ IT-94-A,, 1999). ICTY makes it clear that there should be sufficient evidence to show that individuals have been attacked in such a way that it is obvious to convince every person that the violence was really targeted against a noncombatant populace, a particular group of individuals selected at random (ICTY, Appeal Chamber, judgment condemning Kunarac Dragoljub, Radomir Kovac and Zoran Vukovic,n'IT-96-23 and IT-96-23/1-A, 2002).

We can say that the crime against humanity affects the welfares of the global community or the greater values of humanity, disrupts global peace and safety as well as constitutes a serious violation of human rights. These acts constitute the rules of jus cogens.

\subsection{Genocide Crime}

According to article II of the Convention on the Prevention and Punishment of the Crime of Genocide in 1948, genocide is "any of the following acts committed with the intention to destroy, a whole or part of a national, ethnical, racial or religious group". Such acts include: killing group members; instigating severe physical or psychological harm to a group member; intentionally imposing harsh living conditions on a group which is a calculated attempt to harm their total or partial physical conditions; killing to avoid procreation within a specific group; compulsory transfer of teenagers from the group to other group (ICC Statute, 1998). Similarly, Article 6 of the ICC Statute of July 17, 1998 reproduces this definition literally and gives a detail meaning of the intention to exterminate, totally or partially, a population and the systematic implementation of this intention.

It is an obvious fact that the crime of genocide is an autonomous crime under this convention that can be come out during war and in peaceful situations. It is imprescriptible because just the passing away of time cannot paralyze the trial of the crime or the execution of the sentence (Convention on the Non-Applicability of Statutory Limitations to War Crimes and Crimes against Humanity, adopted by UN/GA, resolution 2391 (XXIII), 1968). On the one hand, it consists of a material element related to the murder of the group, severe physical or psychological harm to any member of a group in order to cause pain or harm to a group which eventually leads to its total or partial destruction, measures that prevent the procreation of the group and the compulsory transfer of one child from a particular group to a different group (ICTR, 1998). On the other hand, there should be an intentional element that shows that the perpetrator tried to provoke the offensive result, which is the entire or part obliteration of a domestic, national, racial or religious group (ICTR, 1998).

In addition, the last element is social which relates to a protected group that make up a certain element of the population whose members have common characteristics that distinguish them from other elements of the population $(E / 447,1947)$. For ICTR judges, the act should be perpetrated against a person because that person is a member of a specific group or because of the person's membership in that group (ICC, Trial Chamber, Prosecutor against Eliezer Niyitegeka, $\mathrm{n}^{\circ}$ ICTR-96-14-T, , 2003).

\subsection{War Crimes}

Article 6 (a) and (b) of the statute of the International Military Tribunal provides an initial definition of war crimes which contains an exhaustive list of breach of the laws and customs of war that falls within the domain of war crimes. These breaches include: the assassination, maltreatment or expulsion of forced labor or any other abuse of persons in their territories, the murder or maltreatment of war prisoners or persons at sea, the execution of captives, the looting of public property or private, the rampant destruction of cities and towns and the devastation that does not justify the needs.

The 1949 Conventions classify some of these acts as serious violations if they are committed against individuals that are under the protection of the 1949 Conventions. The wording appears to be identical in Conventions I and II (Articles 50 and 51). It states that these are acts committed against people or properties. According to the convention: intentional homicide, torment or inhumane treatment, comprising biological tests that intentionally cause excessive misery or severe damage to the body or wellbeing, damaging and seizure of property, without 
justification by military needs and carried out on a huge scale illegally and arbitrarily all fall within this category.

Therefore, the ICTR consider violations of Article 3 of the Geneva Conventions and the Additional Protocol (II) of 1977 on the protection of victims of non-international conflicts as serious violations (Geneva Conventions of 1949 and II Additional Protocols, 1977). Currently, the ICC is using these definitions to compile a list of activities that are considered as war crimes (ICC Statute, 1998). The classification of a conduct as a war crime requires the presence of armed conflict, the presence of a criminal act and a causal link between the conflict and the criminal act.

\subsection{Ethnic Cleaning}

There is no exact definition for the term ethnic cleansing. The Committee of Experts for the former Yugoslavia believed that ethnic cleansing is about making an area ethnically same by the use of force or terrorization to eliminate people belonging to specific groups in the area in question. The General Assembly and the United Nation's Security Council generally refer to this as a serious violation of human rights and international humanitarian law. Ethnic cleansing therefore includes but not limited to: the forced expulsion of civilians and the deprivation of their right of residence and property, mass murder, forceful acquisition of territory, immense, prearranged and orderly confinement, the rape of women and the existence of concentration camps and detention camps (Doc. Off. NU AG A/RES/47/121 , 1992). Public international law provides the following definition "Ethnic cleansing refers to the forced displacement or displacement destined for an entire or part damage of a national, cultural, tribal or religious group in order to achieve ethnic homogeneity in a given territory" (Jean, 2001, p. 736).

To determine this, it should be established and proven with evidence that the victim population was targeted due to their ethnic characteristics. Therefore, it consists of eliminating an undesirable population from the territory in order to obtain a homogenized society. Rape and other sexual violations, hunger, poor sanitation, scorched earth politics, razed villages constitute various forms of ethnic cleansing. Ethnic cleansing is distinguished from genocide by its purpose. The purpose of genocide is to eradicate people, while the purpose of ethnic cleansing is to destroy a territory however, both belong to the category of mass crimes (Semilin (J), 2002), (Rosière, 2006, p. $6)$.

\section{The Justification for Limiting Amnesty in International Law}

United Nations practice appears to justify the prohibition of amnesty measures for crimes against humanity, war crimes, massacre and ethnic cleansing. The Secretary-General's report on the formation of a distinct court for Sierra Leone is one example. He said that while acknowledging that amnesty is a recognized legal standard which represents a sign of peace and understanding at the end of a civil war or domestic armed conflict, the United Nations has steadily declared that amnesty could not be given in relation to international crimes, which include genocide, crimes against humanity or other severe abuses of international humanitarian law (Delmas-Marty, 2009). From a legal assessment, these crimes are recognized as imprescriptible under article 29 of Rome Statute.

Therefore, a question arise as to how a judge is to resolve the issue concerning how long amnesty is valid as provided for in the 1999 Lomé peace agreement. On March 13, 2004, the Special Court for Sierra Leone issued a decision on the issue of amnesty envisaged in Lomé 1999, refusing to acknowledge the applicability of the domestic amnesty to crimes that are perpetrated against humanity and war crimes (SCSL, SCSL-04-15-PT-060- , SCSL-04-15-PT-060-II/Cas NSCSL-2004-15-1R72 (E), Cas N SCSL-2004-16-1R72 (E), 2004). Although the defense classified the Special Court as an international tribunal, before deciding that the general amnesty granted by the Lomé agreement did not prevent international or even foreign courts from prosecuting those that engaged in committing such crimes against humanity and war crimes. In its decision, the Court also took into account the instructions given by the Secretary General to his special representative for Sierra Leone to add to the Lomé agreement a provision specifying that the amnesty measure could not be applied to crimes of international massacre, crimes against humanity and other severe violations of international humanitarian law (SCSL, SCSL-04-15-PT-060- , SCSL-04-15-PT-060-II/Cas NºSCSL-2004-15-1R72 (E) , Cas N SCSL-2004-16-1R72 (E), 2004).

In its decision on May 25, 2004, the case of "Allieu Kondewa" (SCSL, Case Vs. M. Kallon and B.B. Kamara, Case Vs A. Kondewa, 2004), his lawyers applied for an appeal with regards to the lack of jurisdiction and the abuse of the trial due to the amnesty provided for in the Lomé agreement. The appeal judges referred to their previous decision of March 13, 2004, and rejected the request on the basis that it could not find any new arguments that could lead them to a change in their jurisprudence as resented by the request. 
It must be noted that these laws are subject to limitation of international immunities designed to protect high-ranking state officials abroad. Therefore, it is accepted that the immunities of officials in an office do not affect the international criminal courts (ICC Statute, 1998). Those who have left office may be prosecuted before a foreign national court for the activities they committed before and after their duties and in a private capacity.

Furthermore, these crimes are characterized by the duality of possible levels of prosecution. In this sense, they are within the scope or jurisdiction of the international and national criminal courts. In fact, according to the preamble of the Rome Statute, the ICC is only plays a complementary role to the national criminal courts, which play a primary role in criminal trials. The states affected by these crimes have the liberty to use their national criminal codes to make judgements on criminal actions within their territory. In claiming this priority over the International Criminal Court, the state that claims to exercise its jurisdiction must demonstrate its capacity to judge and its true disposition to do so (ICC Statute, 1998).

For example, the Sudanese government, following the issuing of an arrest warrant by the ICC against three of its leaders, which includes the current president, Omar Al-Bashir, for extermination, forced transfer, torture and rape that constitute crimes against humanity created special courts to prove crimes perpetrated against humanity and war crimes carried out in Darfur. Although Sudan is not a signatory to the Rome Statute, the United Nations Security Council referred the situation to the ICC. Therefore, the state argued that the ICC has complementary jurisdiction to judge its own leaders. However, it is not certain that, for this type of crime, national courts always have the independence and impartiality necessary to try state leaders who allegedly perpetrated crimes against their population. Furthermore, this doubt, as noted by the ICC, could justify the refusal of the challenge to admissibility raised by the Libyan authorities in the case of Saif Al-Islam Gaddafi (ICC, Pre-Trial Chamber, The Prosecutor v. Saif Al-Islam Gaddafi, , 2020). He was suspected of two charges of crimes against humanity (murder and persecution) committed during the Libyan revolution of 2011. The Prosecutor claimed that he has an obligation to surrender him to the court but until this day, the suspect has not been detained by the ICC. Put differently, even if the State has the right to try or grant amnesty to them in its territory, customary international law recognizes, with regard to these categories of crimes, a principle of universal and optional subsidiary jurisdiction for all States (Cassese, 2002, p. 673).

Of course, this universal character requires mutual cooperation and mutual legal assistance between states and criminal courts. The fact that for example the ICTR was formed by a Security Council decision adopted in agreement with Chapter VII of the Charter is in itself positive. This means that all states should take all necessary measures to enforce this decision. Therefore, in practice, every State is obliged to cooperate and assist the Tribunal at every stages of the procedure, to ensure that demands for help to gather evidence or to hear witnesses, suspects and experts, or searching for people to assist in providing evidence to a case s are adhered to. Similarly, they must also execute orders from the Chambers of Evidence, such as arrest, search or transfer orders, and comply with any other judicial decision. The 2005 World Summit Document on the Responsibility to Protect further reinforces this principle, as its pillars place an obligation on States and the international community to prevent, act as well as halt the execution of any activity that will constitute crimes against civilian populations. .

\section{Conclusion}

Amnesty which is sometimes called Post-war forgiveness is a necessary evil. Around the world, it paved the way for national reconciliation for lasting peace and facilitated the rebuilding of conflict-torn societies through the deportation of refugees, the coming back of internally displaced persons, the integration and reintegration of ex-combatants. However, responding to international crimes remains an erga omnes obligation of the international community and is essential because amnesty can jeopardize the fundamental rights of victims in post-war countries and expand the culture of impunity.

In terms of recommendations, it would be useful to: respect the rights of victims through transitional justice; compensate victims and their families who have suffered physical, material or financial damage; care for the minor and children whose parents are missing due to the conflict.

\section{References}

Caron, J.-C. (2012). Frères de Sang- La guerre civile en France au XIX siècle. Seyssel: Champ vallon.

Cassese, A. D.-M. ( 2002). Juridictions nationales et Crimes internationaux. Paris: PUF. https://doi.org/10.3917/puf.delm.2002.01

Convention international sur l'élimination et la répression du crime d'apartheid par l'Assemblée général des Nations Unis. (1973, Novembre 30). 
Convention on the Non-Applicability of Statutory Limitations to War Crimes and Crimes against Humanity, adopted by UN/GA, resolution 2391 (XXIII). (1968, November 26).

décret, L. (1791, septembre 14 ). Instaurant une amnistie générale pour les révolutionnaires, les contre-révolutionnaires. Paris.

Delmas-Marty, M. F. (2009). Le Crime contre l'Humanité, Que sais-je ? Paris: PUF.

Doc. Off. NU AG A/RES/47/121. (1992, décembre 18).

E/447, D. C. (1947, juin 26). Projet de Convention sur le génocide présenté par le SG du Conseil économique et social.

Geneva Conventions of 1949 and II Additional Protocols, 1977. (s.d.).

Guillien, R. V. (2003). Lexique des Termes Juridiques. Paris: Dalloz.

ICC. (2003, mai 16). Trial Chamber, Prosecutor against Eliezer Niyitegeka, $\mathrm{n}^{\circ}$ ICTR-96-14-T.

ICC. (2020, March). Pre-Trial Chamber, The Prosecutor v. Saif Al-Islam Gaddafi.

ICC Statute. (1998, july 17). Rome.

ICTR. (1998, September 12). Trial Chamber, Prosecutor C. jean- PaulI Keysu, $n^{\circ}$ ICTR-4-T.

ICTY. (1999, July 15). Appeal Chamber, judgment condamning Dusko Tadic, n IT-94-A.

ICTY. (2002, june 22). Appeal Chamber, judgment condemning Kunarac Dragoljub, Radomir Kovac and Zoran Vukovic, ${ }^{\circ}$ IT-96-23 and IT-96-23/1-A.

ICTY Statute. (1993, May 25).

Jean Salmon. (2001). Dictionnaire de Droit international public. Bruxelles: Bruylant.

Jean, S. (2001). Dictionnaire de Droit international Public. Bruxelles: Bruylant.

Koudou, G. B. (2004). Amnistie et Impunitén des crimes internationaux. 67-95.

No2019-042/AN-RM, L. (2019, Juillet 24). Portant loi d'entente nationale au Mali. Bamako, Mali.

Resolution 47/133, A. O. (1992, décembre 12). Déclaration sur la protection de toutes les personnes contre les disparitions forcées.

Rosière. (2006). Le Nettoyage ethnique, Terreur et peuplement. Paris. Paris: Ellipses.

SCSL. (2004, Mai 25). Case Vs. M. Kallon and B.B. Kamara, Case Vs A. Kondewa.

SCSL. (2004, mars 13). SCSL-04-15-PT-060- , SCSL-04-15-PT-060-II/Cas NSCSL-2004-15-1R72 (E), Cas N ${ }^{\circ}$ SCSL-2004-16-1R72 (E).

Semilin. (2002, Avril). Du Massacre au processus Génocidaire. https://doi.org/10.3917/riss.174.0483

Stéphane Gacon. (2009, novembre 16). Au commencement était la guerre civile. archive, la vie des idées.

Wahnich, S. (2007). Une histoire politique de l'amnistie. Paris: PUF. https://doi.org/10.3917/puf.wahn.2007.01

\section{Copyrights}

Copyright for this article is retained by the author(s), with first publication rights granted to the journal.

This is an open-access article distributed under the terms and conditions of the Creative Commons Attribution license (http://creativecommons.org/licenses/by/4.0/). 